\title{
Australian Journal of Crop Science \\ Influence of salicylic acid (SA) and ascorbic acid (ASA) on in vitro propagation and salt tolerance of date palm (Phoenix dactylifera L.) cv. 'Nersy'
}

\author{
Ahmed Madi Waheed AL-Mayahi \\ Department of Plant Tissue Culture, Date Palm Research Centre, University of Basra, Basra, Iraq
}

*Corresponding author: hng_1988@yahoo.com

\begin{abstract}
This study was carried out to investigate the antioxidant effects of salicylic acid (SA) and ascorbic acid (ASA) under two stress levels (75 and $150 \mathrm{mM} \mathrm{NaCl}$ ) on growth and some biochemical constituents of date palm cv. Nersy cultured in vitro. Micro-propagated shoots of cv. Nersy at length $2.5-3 \mathrm{~cm}$ was excised from the proliferation medium and were separately cultured on MS medium. The data indicated that maximum growth and chlorophyll content of shoots was observed after 75 days of culturing in the medium supplemented with $50 \mathrm{mgl}^{-1}$ salicylic acid and $100 \mathrm{mgl}^{-1}$ ascorbic acid in both stress and non-stress conditions. It was also observed that the in vitro-grown plants resulted increased activities of antioxidant enzymes SOD and APX in medium containing of salicylic acid $\left(75 \mathrm{mgl}^{-1}\right)$ and ascorbic acid $\left(100 \mathrm{mgl}^{-1}\right)$ with increasing salt stress (up to $150 \mathrm{mM}$ of $\mathrm{NaCl}$ ) compared with other treatments. The study of shoot protein patterns using SDS-PAGE showed some remarkable changes in protein expression. The results suggests that the stress induced the synthesis of proteins bands with MW of 15, 29, $43 \mathrm{kD}$ and 15, 22.6, 35 and $46 \mathrm{kD}$ in medium supplement with 75 and $150 \mathrm{mM} \mathrm{NaCl}$, respectively, compared with control treatment (20.9, 28.39, 37, 40 and 48.6) kD. Supplementing salicylic acid $\left(75 \mathrm{mgl}^{-1}\right)$ and ascorbic acid $\left(100 \mathrm{mgl}^{-1}\right)$ under salt stress condition induced the synthesis of additional protein bands with MW of $19.28,28.50,32.61,59.12$ and $72.00 \mathrm{KD}$ at $75 \mathrm{mM} \mathrm{NaCl}$; and $17.96,22.6,31.9554 .50$ and 68.0 at $150 \mathrm{mM} \mathrm{NaCl}$.
\end{abstract}

Keywords: Antioxidant compound, Date palm, Micropropagation, Salt stress, SDS-PAGE.

Abbreviations NAA_naphthalene acetic acid, NOA_naphthoxy acetic acid, SA_Salicylic acid, ASA_Ascorbic acid, SOD_Superoxide dismutase, APX_Ascorbate peroxidise.

\section{Introduction}

Date palm (Phoenix dactylifera L.) belongs to the monocotyledonous family Arecaceae and is an economically important tree species predominantly concentrated in arid regions of the Middle East and North Africa (Zaid, 2002). Plants are usually exposed to different environmental stresses which limit their growth and productivity (Shao et al., 2008). One of the most important factors affecting plant growth and the production of secondary metabolites is the salt stress (Nikolova and Ivancheva, 2005). It is estimated that about one-third of the world's cultivated land is affected by salt (Kaya et al., 2002). The physiological processes are affected by salt stress including ion toxicity, osmotic stress, nutrient deficiency and especially oxidative stress (Flowers, 2004). Formation and accumulation of reactive oxygen species (ROSs) can be induced by salt stress (Erda et al., 2011). Adaptation to salinity encompasses complex processes involving numerous changes such as weak growth, the induction or increased expression of special genes, transient increases in plant regulators levels, accumulation of osmolytes and protective proteins, elevated antioxidative activities and suppression of energy consuming pathways (Bartels and Sunkar, 2005). The free proline assays revealed that this amino acid over-accumulated in the roots and leaves of each stress treated plant. It is remarkably high when leaves are exposed to suboptimum temperatures and salinity stress. These results indicate that the production of proline is a common response to various abiotic stresses (Yaish 2015). Addition of $\mathrm{K}^{+}$to the salt containing media of date palm has reduced the absorption of $\mathrm{Na}^{+}$and also balanced ions compartmentalization. This improvement in growth is accompanied by a decrease in $\mathrm{Na}^{+}$concentration and an increase in $\mathrm{K}^{+}$concentration in the plant tissues with lower $\mathrm{Cl}^{-}$concentrations in leaves and roots of date palm (Alkhateeb et al., 2015). Some results have revealed the identification of miRNAs that share common biogenesis, structure, and expression features with the miRNAs that have been isolated from other plant species. These miRNAs and their targets could play a critical role in the date palm tree, which has the ability to grow under severe environmental conditions, including high temperature, drought, and salinity (Yaish et al., 2016). The development of methods to induce stress tolerance in plants is vital and still receives considerable attention. Choudhury and Panda, (2004) demonstrated that SA has ability to modulate plant response to wide range of oxidative stresses and regulate the activities of antioxidant enzymes and increase plant tolerance to a biotic stress. The ascorbic acid (ASA) plays a multiple roles in plant growth, functioning in cell division, cell wall expansion, and other development processes (Erda et al., 2011; Pignocchi and Foyer, 2003) .In addition, ascorbic acid is a key substance in the network of plant antioxidants (Noctor and Foyer, 1998). Yet, little information is available on the effect of salicylic acid and ascorbic acid on salt stress or enzyme activity in date palm plants. Therefore, the present research was conducted to evaluate the possibility of application of antioxidant compounds such as salicylic acid (SA) and ascorbic acid (ASA) to alleviate harmful effects of 
salinity on date palm cv. Nersy plants growth on in vitro culture condition. We also study some important biochemical changes involved in tolerance to salinity.

\section{Results}

\section{Effect of salicylic acid (SA) and ascorbic acid (ASA) on} some growth criteria

Data in the Table 2 indicate that SA and ASA treatment improved the growth characters at all levels of salt stress and also non-stress plants, compared with control. The greatest shoot length, number of leaves and root length are related to the plants which were cultured under the salt stress with concentration $(75 \mathrm{mM})$ of $\mathrm{NaCl}$ in combination with $50 \mathrm{mgl}^{-}$ ${ }^{1}$ salicylic acids and $100 \mathrm{mgl}^{-1}$ ascorbic acid (Fig.2C). The maximum reduction in growth criteria was observed in plants which were cultured under the salt stress with concentration of $150 \mathrm{mM}$ in combination with $0 \mathrm{mgl}^{-1}$ salicylic acid and 0 $\mathrm{mgl}^{-1}$ of ascorbic acid.

Impact of salicylic acid and ascorbic acid on some biochemical traits

\section{Photosynthetic pigments}

Table 3 shows that the greatest amount of chl $a$, chl $b$ and total chlorophyll are related to the plants which were cultured under the salt stress with concentration $75 \mathrm{mM}$ in combination with $50 \mathrm{mgl}^{-1}$ salicylic acids and $100 \mathrm{mgl}^{-1}$ ascorbic acid. The least amount of chl $a$, chl $b$ and total chlorophyll were related to the plants cultured under the salt stress $(150 \mathrm{mM})$ in combination with $0 \mathrm{mgl}^{-1}$ salicylic acid and $0 \mathrm{mgl}^{-1}$ ascorbic acid.

\section{Superoxide dismutase (SOD) and ascorbate peroxidise activity (APX).}

Table 4 shows that the high levels of antioxidant enzymes activity of SOD and APX were occurred in the shoots cultured under the salt stress $(150 \mathrm{mM})$ in combination with $75 \mathrm{mgl}^{-1}$ salicylic acids and $100 \mathrm{mgl}^{-1}$ ascorbic acid, compared to other treatments. The results of experiment also indicate the least activities of SOD and APX were achieved in control treatment, followed by salt stress $(75 \mathrm{mM})$ in combination with $0 \mathrm{mgl}^{-1}$ salicylic acid and $0 \mathrm{mgl}^{-1}$ ascorbic acid.

\section{SDS-PAGE protein patterns}

Changes of protein patterns were analyzed in leaves of date palm plants $\mathrm{cv}$. Nersy at in vitro culture condition to understand any possible alterations in gene expression in plants cultured under two levels of salt stress (75 and 150 $\mathrm{mM}$ ) of sodium chloride $(\mathrm{NaCl})$ in the absence or presence of SA and ASA comparing with non-salt stressed "control treatment", using SDS-PAGE. The salinity treatments resulted in the induction of new bands with molecular weight of 15,29 and $43 \mathrm{KD}$ in shoots under $75 \mathrm{mM}$ of $\mathrm{NaCl}$; and 15 , 22.6, 35 and $46.0 \mathrm{KD}$ in plants treated with $150 \mathrm{mM} \mathrm{NaCl}$ (Fig. 2, Lane 2 and 3). We observed that salt stress in SA and ASA treated plants induced variation in the appearance of new protein bands and disappearance of some others (differentially expressed proteins) with different molecular weights. The analysis of protein patterns indicates that in non-stressed plants and those cultured in media supplemented with SA, ASA no protein bands and pattern was changed, compare to control treatment, while in salt-stressed plants application of SA, ASA individually or in combination allowed the synthesis of additional new protein bands. The salt-stressed plants treated with $75 \mathrm{mgl}^{-1} \mathrm{SA}+100 \mathrm{mgl}^{-1}$ ASA showed the most enhancement of protein synthesis, compared to those treated with individual application of salicylic acid and ascorbic acid. In plants treated with $75 \mathrm{mgl}^{-}$ ${ }^{1} \mathrm{SA}+100 \mathrm{mgl}^{-1}$ ASA bands were revealed as 19.28, 28.50, $32.61,59.12$ and $72.00 \mathrm{KD}$ at $75 \mathrm{mM} \mathrm{NaCl} ; 17.96,22.6$, 31.9554 .50 and 68.0 at $150 \mathrm{mM} \mathrm{NaCl}$ (Fig. 2, Lane 18 and 19 ), while treatment of shoots with SA or ASA individually, caused a little change and induced only two or three new polypeptides at 75 and $150 \mathrm{mM} \mathrm{NaCl}$ (Fig. 2, Lane 6, 7, 8, 9, $12,13,14$ and 15) .

\section{Discussion}

Reduction in growth parameters with increasing the salinity levels can be attributed to different physiological changes like photosynthesis reduction, protein dehydration and toxic effect of ions accumulation in plant tissue. This study clearly demonstrated that salt stress on date palm plants can significantly be alleviated by the application of salicylic acid (SA) and ascorbic acid (ASA) treatments. The SA and ASA play important roles in the defense response to stresses (salts, water, etc.) in many plant species (Senaratna et al., 2000). It is reported that SA-induced plant growth could be attributed to the enhanced activity of antioxidants that protect the plants from oxidative damages (El-Tayeb, 2005). Application of salicylic acid has helped increasing of plant growth in saline conditions (Stevens et al., 2006). Ascorbic acid perhaps also minimized the oxidative damage by increasing the amount of antioxidant enzymes that, in turn, leads to better growth in the date palm plant cv. Nersy at in vitro conditions.

The results are in agreement with those reported by Amin et al. (2008), who found a progressive increase in plant height, by increasing ascorbic acid level. Smrinoff and Wheeler, (2000) reported that the ASA counteracts with the harmful effects of salinity on plant height and root length at all salinity levels. These results are in coincidence with that cited by Azooz et al. (2004). Athar et al. (2008) suggested that ascorbic acid could accelerate cell division and improve the growth. Some signs of environmental stresses in plants are reduction of chlorophyll. However, this reduction remarkably depends upon the plant genotype (Colom and Vazzana, 2001). The chlorophylls ( $a$ and b) play important role in photosynthesis. The chlorophyll content reduction was reported in salt stressed date palm (AL- Mayahi, 2015). Decreases in photosynthetic pigments were due to instability of protein complexes and destruction of chlorophyll by increased activity of chlorophyll degrading enzymes and chlorophyllase under high stress condition. Based on the theory of Schutz and Fangmir (2001), the reduction of chlorophyll due to stress is related to the increase of production of reactive oxygen species (ROS) in the cell. These free radicals cause peroxidation, disintegration and reduction of chlorophyll content in plants under stressful conditions. The SA application triggers scavenging of ROS that may increase $\mathrm{Chl}$ content in date palm. The SA-induced salt tolerance in date palm plants might be associated with an increase in the activity of ascorbate peroxidase and superoxide dismutase. 
Table1. Treatments that applied in this study.

\begin{tabular}{|c|c|c|c|}
\hline No. & Treatments & No. & Treatments \\
\hline 1 & $0 \mathrm{mM} \mathrm{NaCl}$ (control) & 11 & $0 \mathrm{mM} \mathrm{NaCl}+100 \mathrm{mg} \cdot \mathrm{l}^{-1} \mathrm{ASA}$ \\
\hline 2 & $75 \mathrm{mM} \mathrm{NaCl}$ & 12 & $75 \mathrm{mM} \mathrm{NaCl}+50 \mathrm{mg} \cdot \mathrm{l}^{-1} \mathrm{ASA}$ \\
\hline 3 & $150 \mathrm{mM} \mathrm{NaCl}$ & 13 & $75 \mathrm{mM} \mathrm{NaCl}+100 \mathrm{mg}^{-1} \mathrm{l}^{-1} \mathrm{ASA}$ \\
\hline 4 & $0 \mathrm{mMNaCl}+50 \mathrm{mg} \cdot .^{-1} \mathrm{SA}$ & 14 & $150 \mathrm{mM} \mathrm{NaCl}+50 \mathrm{mg} \cdot \mathrm{l}^{-1} \mathrm{ASA}$ \\
\hline 5 & $0 \mathrm{mM} \mathrm{NaCl}+75 \mathrm{mg} \cdot \mathrm{l}^{-1} \mathrm{SA}$ & 15 & $150 \mathrm{mM} \mathrm{NaCl}+100 \mathrm{mg} \cdot \mathrm{l}^{-1} \mathrm{ASA}$ \\
\hline 6 & $75 \mathrm{mMNaCl}+50 \mathrm{mg} \cdot 1^{-1} \mathrm{SA}$ & 16 & $75 \mathrm{mMNaCl}+50 \mathrm{mg} \cdot \mathrm{l}^{-1} \mathrm{SA}+100 \mathrm{mg} \cdot \mathrm{l}^{-1} \mathrm{ASA}$ \\
\hline 7 & $75 \mathrm{mM} \mathrm{NaCl}+75 \mathrm{mg} \cdot \mathrm{l}^{-1} \mathrm{SA}$ & 17 & $150 \mathrm{mM} \mathrm{NaCl}+50 \mathrm{mg} \cdot \mathrm{l}^{-1} \mathrm{SA}+100 \mathrm{mg} \cdot \mathrm{l}^{-1} \mathrm{ASA}$ \\
\hline 8 & $150 \mathrm{mMNaCl}+50 \mathrm{mg} \cdot \mathrm{l}^{-1} \mathrm{SA}$ & 18 & $75 \mathrm{mM} \mathrm{NaCl}+75 \mathrm{mg} . \mathrm{l}^{-1} \mathrm{SA}+100 \mathrm{mg} . \mathrm{l}^{-1} \mathrm{ASA}$ \\
\hline 9 & $150 \mathrm{mM} \mathrm{NaCl}+75 \mathrm{mg} \cdot \mathrm{l}^{-1} \mathrm{SA}$ & 19 & $150 \mathrm{mM} \mathrm{NaCl}+75 \mathrm{mg} \cdot \mathrm{l}^{-1} \mathrm{SA}+100 \mathrm{mg} \cdot \mathrm{l}^{-1} \mathrm{ASA}$ \\
\hline 10 & $0 \mathrm{mM} \mathrm{NaCl}+50 \mathrm{mg} \cdot 1^{-1} \mathrm{ASA}$ & & \\
\hline
\end{tabular}

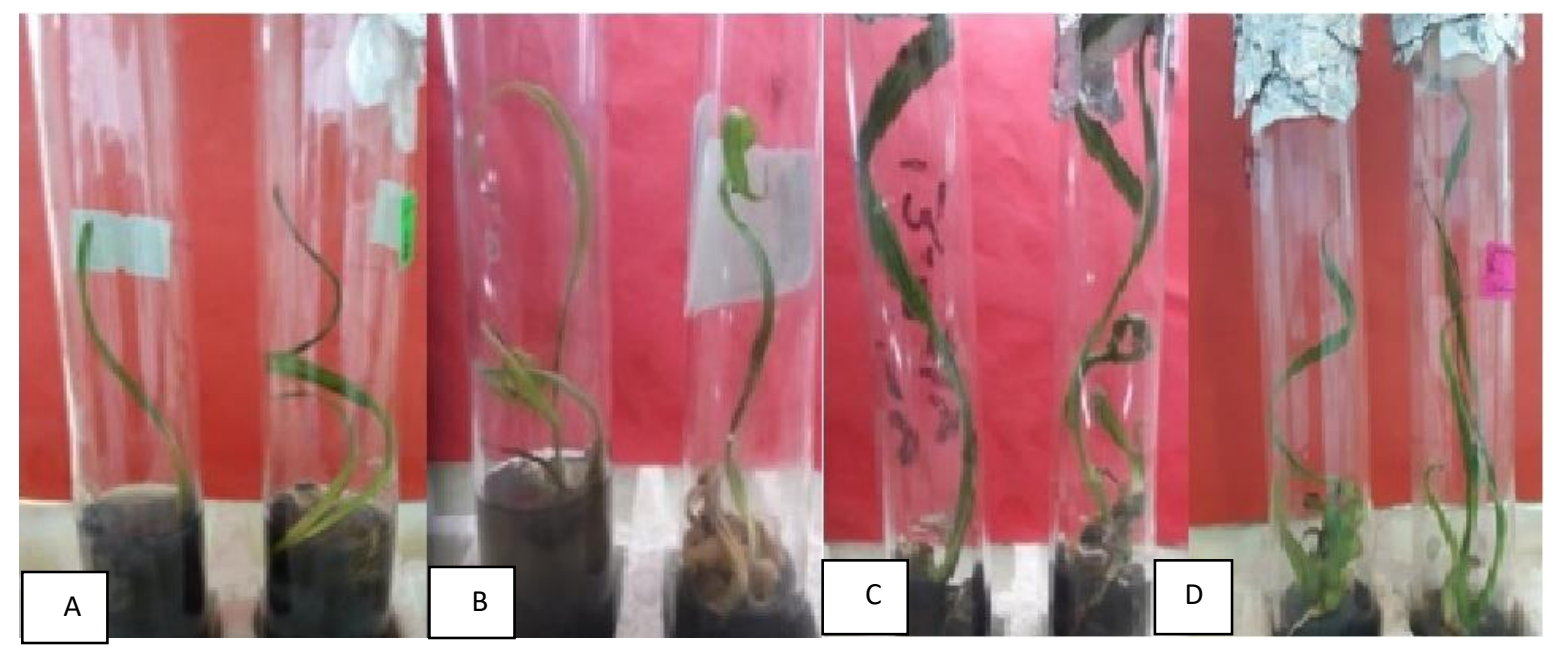

Fig 1. Effect of salicylic acid (SA) and ascorbic acid (ASA) on shoot and root length, number of leaves and roots of date palm cv. Nersy plantlets under different concentrations of NaCl. (A) Treated with $75 \mathrm{mM} \mathrm{NaCl}$; (B) Treat with $75 \mathrm{mM} \mathrm{NaCl}+100 \mathrm{mg} .1^{-1}$ ASA; (C) Treated with $75 \mathrm{mM} \mathrm{NaCl}+50 \mathrm{mg} \cdot \mathrm{l}^{-1} \mathrm{SA}+100 \mathrm{mg} \cdot \mathrm{l}^{-1}$ ASA (D) Treated with $75 \mathrm{mM} \mathrm{NaCl}+75 \mathrm{mg} \cdot \mathrm{l}^{-1} \mathrm{SA}+100 \mathrm{mg} \cdot \mathrm{l}^{-1}$ ASA.

Therefore, impact of salicylic acid on chlorophyll may be related with its influence on the anti-oxidative enzyme activities. Salicylic acid regulates physiological and biochemical processes in plants and can be used as a potential growth regulator to improve plant growth under saline conditions. This positive effect of SA could be attributed to an increased $\mathrm{CO}_{2}$ assimilation and photosynthetic rate and increased mineral uptake by the stressed plant under SA treatment. On the other hand, ascorbic acid also beneficially influences damage reduction which is caused by salt. This may be due to salinity resulting in increased activity of reactive oxygen species (ROS) which may cause severe cellular damage. In this study, it was found that ascorbic acid plays an important role in photosynthetic pigments to defend system against oxidative stress. It is a powerful reducing agent found usually in small concentrations in plants, and is proposed to play an important role in scavenging reactive oxygen species $\left(\mathrm{O}_{2}, \mathrm{H}_{2} \mathrm{O}_{2}, \mathrm{OH}-\right.$ etc. $)$ generated during stress conditions in plants (Smirnoff, 2005). Furthermore, ascorbic acid (ASA) also benefitted growth which may be due to the antioxidant activity of ascorbic acid protecting plants from damage due to a biotic stress (Beltagi, 2008). The present study confirmed pervious observations and reports that application of SA under stressed conditions improved plants performance in terms of enhanced chlorophyll contents (Agarwal et al., 2005). This result is in agreement with those reported by Khan et al. (2003), who found that SA increased the photosynthetic rate in corn and soybean. Also, Farahat et al. (2013) found that the combined treatment of ascorbic acid with salinity level gave significantly increased chlorophyll a, b, and total chlorophyll content of shoots, compared with control plants. The role of application of ASA in wheat has also been reported earlier (Athar et al., 2008), where an increase in photosynthetic activity was noted as a result of ASA application resulted in overcoming damaging effect of salt stress. This result indicated that oxidative stress is one of the main consequences of salinity stress on date palm and SA with ASA has an ameliorative effect on this process. The SA application may cause a temporary and low level of oxidative stress in plants, which acts as a hardening process improving the anti-oxidative capacity of plants and helping to induce the synthesis of protective compounds and; therefore, the acclimation to stress (Janda et al., 2007). These results indicated that increased APX activity could be an adaptive mechanism to an increased oxidative stress which caused by salinity. Furthermore, SA intensified APX activity to facilitate oxidative damage protection. Salicylic acid has an affinity to bind with the enzymes APX (Slaymaker et al., 2002) which are involved in ROS metabolism and redox homeostasis. Alteration in this homeostasis leads to induction of a defense response in plants (Mittler, 2002). Increasing APX activity as a consequence of exogenous SA application was also reported by (Agarwal et al., 2005).

Regarding SOD, the results indicated that the activity of SOD was affected variously under salinity, SA, ASA levels. We also noticed interaction among effects of salinity, SA, ASA levels. The results of this study showed that salt stress had significant effects on the enzymes activity in shoots. Different abiotic stresses may provoke oxidative stress, leading to cellular adaptive responses such as acceleration 
Table 2. Effect of salicylic acid (SA) and ascorbic acid (ASA) on in in vitro growth of date palm cv. Nersy under different concentrations of $\mathrm{NaCl}$.

\begin{tabular}{|c|c|c|c|c|}
\hline \multirow{2}{*}{ Treatments } & \multirow{2}{*}{ Growth attributes } & \multicolumn{3}{|c|}{$\mathrm{NaCl}$ Cons (mM) } \\
\hline & & 0.0 & 75 & 150 \\
\hline \multirow{3}{*}{0.0} & Shoot Length & $6.90 \pm 0.55 \mathrm{ghi}$ & $6.77 \pm 0.81 \mathrm{hi}$ & $5.50 \pm 0.43 \mathrm{~g}$ \\
\hline & No. of leaves & $1.67 \pm 0.19 \mathrm{ef}$ & $1.67 \pm 0.21 \mathrm{ef}$ & $1.16 \pm 0.26 \mathrm{~h}$ \\
\hline & Root Length & $4.0 \pm 0.54 \mathrm{c}$ & $3.8 \pm 0.84 \mathrm{~d}$ & $2.6 \pm 0.64 \mathrm{~g}$ \\
\hline \multirow{3}{*}{$50 \mathrm{SA}$} & Shoot Length & $7.80 \pm 0.65 \mathrm{defg}$ & $7.94 \pm 0.4 \mathrm{cdef}$ & $6.91 \pm 0.75 \mathrm{ghi}$ \\
\hline & No. of leaves & $1.67 \pm 0.019 \mathrm{ef}$ & $1.83 \pm 0.15 \mathrm{de}$ & $1.33 \pm 0.21 \mathrm{gh}$ \\
\hline & Root Length & $4.6 \pm 0.38 \mathrm{abc}$ & $3.8 \pm 0.45 \mathrm{~d}$ & $2.8 \pm 0.47 \mathrm{~g}$ \\
\hline \multirow{3}{*}{$75 \mathrm{SA}$} & Shoot Length & $7.19 \pm 067$ fghi & $7.37 \pm 0.48$ efghi & $6.40 \pm 0.43 \mathrm{ij}$ \\
\hline & No. of leaves & $1.33 \pm 0.13 \mathrm{gh}$ & $1.50 \pm 0.0 .2 \mathrm{fg}$ & $1.16 \pm 0.0 .08 \mathrm{~h}$ \\
\hline & Root Length & $3.8 \pm 0.45 \mathrm{~d}$ & $3.77 \pm 0.42 \mathrm{def}$ & $2.5 \pm 0.64 \mathrm{~g}$ \\
\hline \multirow{3}{*}{50 ASA } & Shoot Length & $7.51 \pm 0.0 .76 \mathrm{efgh}$ & $7.63 \pm 0.50 \mathrm{defgh}$ & $6.65 \pm 0.081 \mathrm{hi}$ \\
\hline & No. of leaves & $1.67 \pm 0.19 \mathrm{ef}$ & $1.83 \pm 0.15 \mathrm{de}$ & $1.33 \pm 0.13 \mathrm{gh}$ \\
\hline & Root Length & $4.3 \pm 0.42 \mathrm{bcde}$ & $4.55 \pm 0.0 .37 \mathrm{abcd}$ & $3.1 \pm 0.47 \mathrm{fg}$ \\
\hline \multirow{3}{*}{100 ASA } & Shoot Length & $8.25 \pm 0.0 .65 \mathrm{bcde}$ & $8.88 \pm 0.0 .95 \mathrm{abc}$ & $7.45 \pm 0.34$ efghi \\
\hline & No. of leaves & $1.83 \pm 0.15 \mathrm{de}$ & $2.00 \pm 0.0 .2 \mathrm{~cd}$ & $1.50 \pm 0.0 .13 \mathrm{fg}$ \\
\hline & Root Length & $4.5 \pm 0.43 \mathrm{abcd}$ & $4.6 \pm 0.38 \mathrm{abc}$ & $3.6 \pm 48 \mathrm{ef}$ \\
\hline \multirow{3}{*}{$50 \mathrm{SA}+100 \mathrm{ASA}$} & Shoot Length & $9.10 \pm 0.55 \mathrm{ab}$ & $9.50 \pm 0.22 \mathrm{a}$ & $7.95 \pm 0.18 \mathrm{cdef}$ \\
\hline & No. of leaves & $2.33 \pm 0.12 \mathrm{ab}$ & $2.50 \pm 0.11 \mathrm{a}$ & $1.83 \pm 0.04 \mathrm{de}$ \\
\hline & Root Length & $4.8 \pm 0.39 \mathrm{ab}$ & $5.1 \pm 0.23 \mathrm{a}$ & $4.0 \pm 0.47 \mathrm{c}$ \\
\hline \multirow{3}{*}{$75 \mathrm{SA}+100 \mathrm{ASA}$} & Shoot Length & $8.53 \pm 0.75 \mathrm{abcd}$ & $9.07 \pm 0.55 \mathrm{ab}$ & $7.63 \pm 0.5 \mathrm{defgh}$ \\
\hline & No. of leaves & $2.00 \pm 0.2 \mathrm{~cd}$ & $2.16 \pm 0.2 b c$ & $1.67 \pm 0.19 \mathrm{def}$ \\
\hline & Root Length & $4.75 \pm 0.25 \mathrm{abc}$ & $4.8 \pm 0.39 \mathrm{ab}$ & $3.75 \pm 0.45 \mathrm{def}$ \\
\hline
\end{tabular}

\pm Standard error
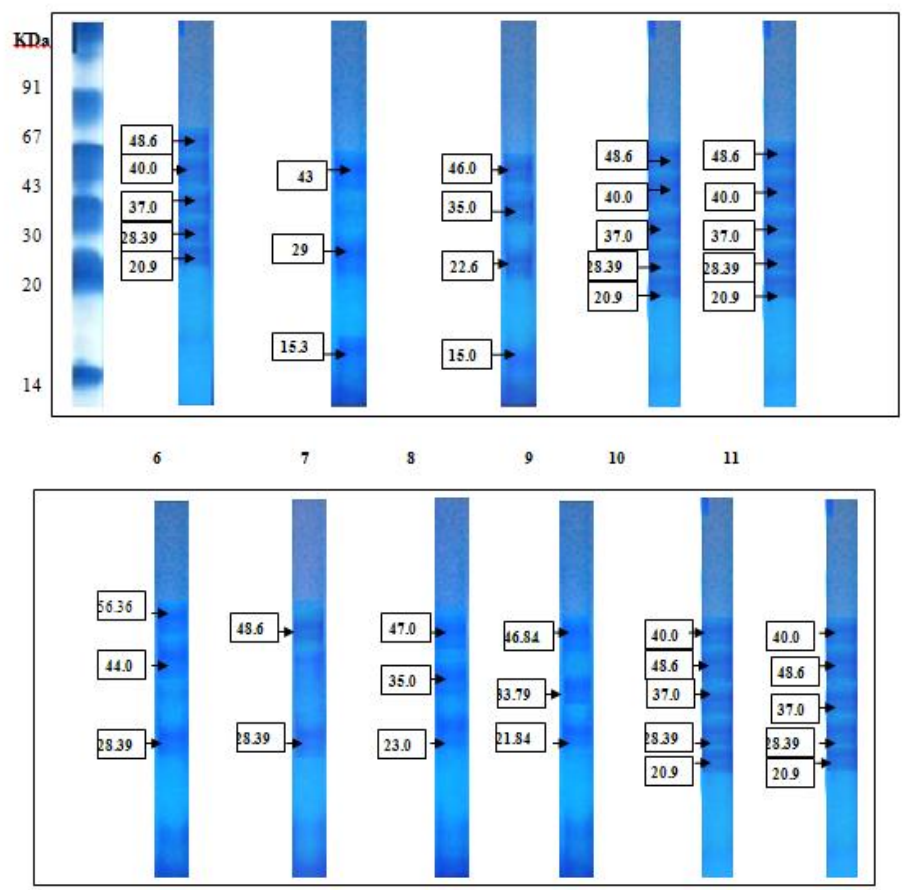

$\begin{array}{llllllll}12 & 13 & 14 & 15 & 16 & 17 & 18 & 19\end{array}$

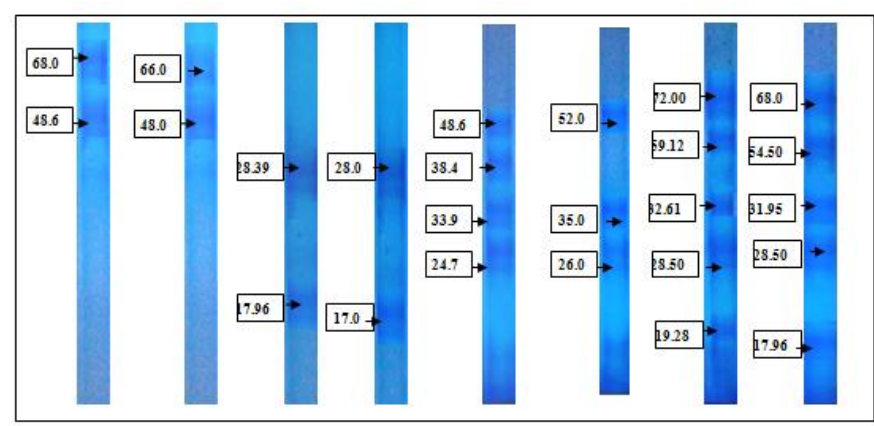

Fig 2. SDS-PAGE of protein extracted from Shoots of date palm cv. Nersy. treated with $\mathrm{NaCl}$, Salicylic acid "SA" and Ascorbic acid "ASA" as shown in Table 1. 
Table 3. SDS-PAGE of protein extracted from Shoots of date palm cv. Nersy . treated with $\mathrm{NaCl}$, Salicylic acid "SA" and Ascorbic acid "ASA", as shown in Table 1.

\begin{tabular}{|c|c|c|c|c|}
\hline \multirow{2}{*}{$\begin{array}{l}\text { Treatments } \\
\text { Mg. } 1^{-1}\end{array}$} & \multirow{2}{*}{$\begin{array}{l}\text { Chlorophylls } \\
\text { ( mg/100 g FW) }\end{array}$} & \multicolumn{2}{|c|}{$\mathrm{NaCl}$ Cons. (mM) } & \multirow[b]{2}{*}{150} \\
\hline & & 0.0 & 75 & \\
\hline \multirow{3}{*}{0.0} & Chl a & $0.783 \pm 0.067 \mathrm{ij}$ & $0.779 \pm 0.023 \mathrm{ij}$ & $0.584 \pm 0.041$ \\
\hline & Chl b & $0.247 \pm 0.002 \mathrm{de}$ & $0.239 \pm 0.007 \mathrm{de}$ & $0.197 \pm 0.003 \mathrm{e}$ \\
\hline & Chl t & $1.030 \pm 0.04 \mathrm{ghi}$ & $1.018 \pm 0.0016 \mathrm{ghi}$ & $0.781 \pm 0.20 \mathrm{j}$ \\
\hline \multirow{3}{*}{$50 \mathrm{SA}$} & Chl a & $0.816 \pm 0.019 \mathrm{i}$ & $0.943 \pm 0.071 \mathrm{~h}$ & $0.739 \pm 0.023 \mathrm{jk}$ \\
\hline & Chl b & $0.268 \pm 0.004 \mathrm{cde}$ & $0.273 \pm 0.005 \mathrm{cde}$ & $0.249 \pm 0.002 \mathrm{de}$ \\
\hline & Chl t & $1.084 \pm 0.13 \mathrm{~g}$ & $1.216 \pm 0.16 \mathrm{f}$ & $0.988 \pm 0.0 .12 \mathrm{hi}$ \\
\hline \multirow{3}{*}{$75 \mathrm{SA}$} & Chl a & $0.809 \pm 0.03 \mathrm{i}$ & $0.935 \pm 0.04 \mathrm{~h}$ & $0.718 \pm 0.023 \mathrm{k}$ \\
\hline & Chl b & $0.251 \pm 0.002 \mathrm{cde}$ & $0.269 \pm 0.004 \mathrm{cde}$ & $0.237 \pm 0.009 \mathrm{de}$ \\
\hline & Chl t & $1.060 \pm 0.061 \mathrm{gh}$ & $1.204 \pm 0.046 \mathrm{f}$ & $0.955 \pm 0.04 \mathrm{i}$ \\
\hline \multirow{3}{*}{50 ASA } & Chl a & $0.983 \pm 0.071 \mathrm{gh}$ & $1.008 \pm 0.13 \mathrm{~g}$ & $0.815 \pm 0.019 \mathrm{i}$ \\
\hline & Chl b & $0.280 \pm 0.058 \mathrm{~cd}$ & $0.300 \pm 0.0001 \mathrm{~cd}$ & $0.257 \pm 0.005 \mathrm{cde}$ \\
\hline & Chl t & $1.263 \pm 0.30 \mathrm{f}$ & $1.308 \pm 0.08 \mathrm{f}$ & $1.072 \pm 0.0 \mathrm{gh}$ \\
\hline \multirow{3}{*}{100 ASA } & Chl a & $1.130 \pm 0.061 \mathrm{e}$ & $1.169 \pm 0.013 \mathrm{de}$ & $0.941 \pm 0.04 \mathrm{~h}$ \\
\hline & Chl b & $0.293 \pm 0.004 \mathrm{~cd}$ & $0.329 \pm 0.008 b c$ & $0.266 \pm 0.002 \mathrm{cde}$ \\
\hline & Chl t & $1.423 \pm 0.0 .23 \mathrm{de}$ & $1.498 \pm 0.023 \mathrm{~cd}$ & $1.207 \pm 0.046 \mathrm{f}$ \\
\hline \multirow{3}{*}{$\begin{array}{l}50 \\
\text { ASA }\end{array}$} & Chl a & $1.390 \pm 0.08 \mathrm{~b}$ & $1.520 \pm 0.20 \mathrm{a}$ & $1.200 \pm 0.046 \mathrm{~d}$ \\
\hline & Chl b & $0.328 \pm 0.008 b c$ & $0.419 \pm 0.009 a$ & $0.289 \pm 0.005 \mathrm{~cd}$ \\
\hline & Chl t & $1.718 \pm 0.41 b$ & $1.939 \pm 0.49 a$ & $1.489 \pm 0.20 \mathrm{~cd}$ \\
\hline \multirow{3}{*}{$\begin{array}{ll}75 & S A+100 \\
\text { ASA } & \end{array}$} & Chl a & $1.266 \pm 0.064 c$ & $1.380 \pm 0.08 \mathrm{~b}$ & $1.067 \pm 0.13 \mathrm{f}$ \\
\hline & Chl b & $0.307 \pm 0.08 \mathrm{bcd}$ & $0.384 \pm 0.016 a b$ & $0.279 \pm 0.004 \mathrm{~cd}$ \\
\hline & Chl t & $1.573 \pm 0.20 \mathrm{c}$ & $1.764 \pm 0.21 b$ & $1.346 \pm 0.0 .08 \mathrm{ef}$ \\
\hline
\end{tabular}

Table 4. Effect of salicylic acid "SA" and ascorbic acid on Superoxide dismutase (SOD) and Ascorbate peroxidise (APX) activity in date palm cv. Nersy plant leaves under concentrations of $\mathrm{NaCl}$ in vitro.

\begin{tabular}{lllll}
\hline \multirow{2}{*}{ Treatment } & Enzymes & \multicolumn{3}{c}{ NaCl Cons. $(\mathrm{mM})$} \\
& & 0.0 & 75 & 150 \\
\hline \multirow{2}{*}{0.0} & SOD & $12.50 \pm 0.41 \mathrm{q}$ & $14.80 \pm 0.66 \mathrm{p}$ & $18.60 \pm 0.76 \mathrm{~m}$ \\
& APX & $0.912 \pm 0.08 \mathrm{~m}$ & $1.231 \pm 0.261$ & $1.650 \pm 0.19 \mathrm{j}$ \\
$50 \mathrm{SA}$ & SOD & $17.30 \pm 0.62 \mathrm{n}$ & $20.86 \pm 0.46 \mathrm{jk}$ & $21.20 \pm 1.6 \mathrm{ij}$ \\
& APX & $1.850 \pm 0.15 \mathrm{i}$ & $2.150 \pm 0.20 \mathrm{~g}$ & $2.350 \pm 0.06 \mathrm{f}$ \\
$75 \mathrm{SA}$ & SOD & $20.5 \pm 1.4 \mathrm{jkl}$ & $22.69 \pm 0.43 \mathrm{e}$ & $25.80 \pm 2.15 \mathrm{e}$ \\
& APX & $2.150 \pm 0.42 \mathrm{~g}$ & $2.500 \pm 0.28 \mathrm{e}$ & $2.850 \pm 0.18 \mathrm{e}$ \\
$50 \mathrm{ASA}$ & SOD & $15.80 \pm 0.30 \mathrm{o}$ & $19.64 \pm 1.011$ & $20.10 \pm 0.17 \mathrm{kl}$ \\
& APX & $1.350 \pm 0.26 \mathrm{k}$ & $1.800 \pm 0.15 \mathrm{i}$ & $2.200 \pm 0.12 \mathrm{~g}$ \\
$100 \mathrm{ASA}$ & SOD & $19.88 \pm 1.071$ & $21.92 \pm 1.16 \mathrm{ij}$ & $23.54 \pm 2.07 \mathrm{~g}$ \\
& APX & $2.000 \pm 0.42 \mathrm{~h}$ & $2.350 \pm 0.4 \mathrm{f}$ & $2.600 \pm 0.19 \mathrm{~d}$ \\
$50 \mathrm{SA}+100 \mathrm{ASA}$ & SOD & $24.50 \pm 1.75 \mathrm{f}$ & $28.00 \pm 1.20 \mathrm{~d}$ & $32.00 \pm 1.95 \mathrm{c}$ \\
& APX & $2.350 \pm 0.06 \mathrm{f}$ & $2.600 \pm 0.3 \mathrm{~d}$ & $3.000 \pm 0.48 \mathrm{~b}$ \\
$75 \mathrm{SA}+100 \mathrm{ASA}$ & SOD & $31.68 \pm 1.65 \mathrm{c}$ & $35.70 \pm 1.75 \mathrm{~b}$ & $40.01 \pm 2.40 \mathrm{a}$ \\
& APX & $2.850 \pm 0.47 \mathrm{c}$ & $3.000 \pm 0.36 \mathrm{~b}$ & $3.350 \pm 0.24 \mathrm{a}$ \\
\hline
\end{tabular}

of ROSs scavenging systems and alteration in antioxidant enzyme activities in plants (Hamdia and Shaddad, 2010). Previously, role of SA was indicated in the induction of antioxidant defenses, maintaining the redox state of the gluthatione pool and plant protection against oxidative stress (Borsani et al. 2001). Therefore, the effects of SA and ASA on date palm plant, grown on salt stress in vitro, were investigated in the present study. Different abiotic stresses may provoke oxidative stress, which lead to cellular adaptive responses such as acceleration of ROSs scavenging systems and alteration in antioxidant enzyme activities in plants (Hamdia and Shaddad, 2010). Modulation of antioxidant systems and the levels of substrates can correlate to tolerance to salinity stress in higher plants (Jahnke and White, 2003). Changes in the levels of antioxidant molecules and the activity of antioxidant enzymes, which are signals of plant tolerance/adaptation to stress conditions, are correlated into oxidative stress tolerance of plants (Lee et al., 2001). Variations in the antioxidant levels can serve as a signal for the modulation of ROSs scavenging mechanisms and ROSs signal transduction (Mittler, 2002). In the present study, enhanced activities of SOD due to SA and ASA addition might have been one of the factors contributing to improved growth in date palm cv. Nersy growing in vitro under saline conditions.

The beneficial effect of SA was also reflected on membrane stability, chlorophylls contents and growth parameters. Similar to the results of this study, some reports have shown that salt stress induces an increase in SOD activity. This has frequently been correlated with plant salt tolerance (Sudhakar et al., 2001). This view was further supported by the arguments that major detoxification of ROS produced during photosynthesis is mediated by superoxide dismutase and by reductive processes involving the major redox buffers of plant cells such as ascorbate (Foyer and Noctor, 2003). Ascorbat has been shown to have a critical role in several physiological processes in plants, including growth, differentiation and metabolism (Foyer, 1993). Likewise by application of ascorbic acid, antioxidant enzyme activities increased significantly in salt-treated date palm plants in 
vitro. Up-regulation in the activity of ascorbat peroxidase and superoxide dismutase indicates that these enzymes are somehow involved in the neutralization process of reactive oxygen species as well. Ascorbic acid protects metabolic processes against $\mathrm{H}_{2} \mathrm{O}_{2}$ and other toxic derivatives of oxygen, which affect many enzyme activities, minimizes the damage caused by oxidative processes through synergistic function with other antioxidants, and stabilizes membranes (Shao et al., 2008). These results are in agreement with those of Dolatabadian and Jouneghani, (2009) who reported that major enzymes as (superoxide dismutase) involved in scavenging reactive oxygen species increase significantly by the application of ascorbic acid to salt stressed bean plants. Higher SOD activity in leaves of plants subjected to foliar application of ASA, SA and $\mathrm{H}_{2} \mathrm{O}_{2}$ at suboptimal temperature stress suggests a more efficient scavenging system, which may protect membranes from injurious effect of ROS (Foyer and Noctor, 2003).

Changes in protein synthesis under salt stress may be due to changes in the efficiency of mRNA translation or the regulation of RNA transcription, transport and stability. The expression of salt-stress proteins is related to the adaptation process of plants to salinity as well as to the genetic constitution of selected salt tolerant genotype. These results confirmed the results reported by El-Bassiouny et al. (2008), who concluded that one of the important mechanism involved in the cell protection against salinity stress is the induction of de novo synthesis of a set of new protein. The salinity altered the protein patterns of two Anabaena strains by inducing the synthesis of specific proteins called the salt-stress proteins that are strain dependent (Apte and Bhagwat, 1998).

The new bands of high molecular weight proteins in salt stressed plants treated with SA and ASA might be due to synthesis of these proteins (Gopala Roa et al., 1987). These new proteins may have a specific function to protect date palm plants from further dehydration damage and considered as a defense mechanism to salt stress. Salt induced polypeptides have been observed in many studies and are assumed to play a role in salt stress tolerance (Jiang and Huang, 2002). The observation of new protein in the present study was confirmed by the earlier work that the proteins are specific to adaptation to salt stress (Gomathi et al., 2013). Expression of $15 \mathrm{kDa}$ polypeptide was observed under a salt stress. In present study, enhanced expression of $72 \mathrm{kDa}$ protein upon SA and ASA indicated that SA and ASA might have induced the protein synthesis under salt stress condition. Such altered and enhanced expression of protein may be responsible for the survival and growth of the plants under high level of $\mathrm{NaCl}$.

Disappearance of certain polypeptides in salt stressed plants in the absence of SA or ASA may be related to increased hydrolysing enzyme RNAase activity (Kong-Ngern et al., 2005). These results were supported by previous studies in other plant species (Azooz et al., 2004; Azooz and Al-Fredan, 2009). The polypeptides that were disappeared during salinity stress might be compensated by others. We also noticed that the applied ASA has a stimulatory effect on the quantitative and qualitative changes in protein biosynthesis. These new protein bands may be due to de novo synthesis of new proteins in plants under 75 and $150 \mathrm{mM} \mathrm{NaCl}$ or in combination with ASA, as reported by other investigators (Azooz et al., 2004; El-Bassuony et al., 2008; Azooz and AlFredan, 2009). They reported that, vitamin treatments induced alterations in the enzymes related to protein metabolism. These enzymes might act as activators of protein synthesis that appeared in plants treated with salinity or/and vitamins. This may play an inductive role in triggering a special defense system, helping these plants to improve their salt tolerance and consequently their growth. El-Bassuony et al. (2008) has shown that vitamin treatments induces a significant alterations in the enzymes related to protein metabolism, which indicates that vitamins might act as activators of protein synthesis.

In addition, the cells exposed to salt stress tend to the production of ABA. This hormone has a relationship to tolerance to the salt stress through the signal transduction leading to the induction of gene 'Gene activation' and the formation of proteins that have the function of protecting osmotic (Munns, 2005).

\section{Materials and methods}

\section{Plant material}

This study conducted in Tissue Culture Laboratory, Date Palm Research Center, Basra University during the period from 2013 and 2014. Micro propagated shoots of date palm cv. Nersy (This cultivar has been chosen because it is one of the rare cultivars and with good quality) at length $2.5-3 \mathrm{~cm}$ was excised from the proliferation medium and were separately cultured on MS medium (Murashige and Skoog, 1962). The culture media consisted of MS salts, supplemented with Myo-Inositol (100 mg. $\left.\mathrm{l}^{-1}\right)$, Glutamine (200 mg. $\left.\mathrm{l}^{-1}\right)$, Thiamine-hydrochloride $\left(1 \mathrm{mg} . \mathrm{l}^{-1}\right)$, nicotinic acid (1mg. $\left.1^{-1}\right)$, Pyridoxine-hydrochloride $\left(1 \mathrm{mg} . \mathrm{l}^{-1}\right)$, sucrose (30g. $\left.1^{-1}\right)$, activated charcoal $\left(0.5\right.$ g..$\left.^{-1}\right)$ and agar $\left(7\right.$ g. $\left.1^{-1}\right)$ and two antioxidant compounds to tolerance salt stress salicylic acid (SA) and ascorbic acid (ASA). The $\mathrm{pH}$ was adjusted to 5.7-5.8 and then the media were autoclaved at $121^{\circ} \mathrm{C}$ for 20 min. Cultures were incubated in the in the growth chambers at $25 \pm 2{ }^{\circ} \mathrm{C}$ under $16 \mathrm{~h}$ photoperiods. Treatments were consisted of 19 media, Salicylic acid (SA), Ascorbic acid (ASA), as well as their interaction with three concentrations of Sodium Chloride as shown in Table 1.

\section{Effect of salicylic acid (SA) and ascorbic acid (ASA) on some growth criteria}

Growth criteria were recorded after 75 days from culture of shoots included all of length of shoots $(\mathrm{cm})$, number of leaves formed and length of roots $(\mathrm{cm})$.

\section{Biochemical and physiological parameters determination}

\section{Assessment of chlorophyll content}

The amount of chlorophylls in the leaves was estimated by the method described by (Porra, 2002).

\section{Estimation of antioxidant enzyme activities}

The activity of superoxide dismutase (SOD; EC 1.15.1.1) was assayed by measuring the inhibition of superoxide-driven nitrite formation from hydroxylamine hydrochloride according to Das et al. (2000). The reaction mixture was prepared by mixing $1.110 \mathrm{ml}$ of $50 \mathrm{mM}$ phosphate buffer $(\mathrm{pH}$ 7.4), $0.075 \mathrm{ml}$ of $20 \mathrm{mM}$ L-methionine, $0.040 \mathrm{ml}$ of $1 \%(\mathrm{v} / \mathrm{v})$ Triton X-100, $0.075 \mathrm{ml}$ of $10 \mathrm{mM}$ hydroxylamine hydrochloride and $0.1 \mathrm{ml}$ of $50 \mu \mathrm{M}$ EDTA. A $100 \mu \mathrm{l}$ of enzyme extract $(50 \mu \mathrm{g}$ protein) and $80 \mu \mathrm{l}$ of riboflavin (50 $\mu \mathrm{M})$ were added to this mixture. The cocktail was mixed and then illuminated for 10 minutes in an aluminium foil-coated wooden box containing two $20 \mathrm{~W}$-Philips fluorescent lamps fitted parallel to each other. The control tube contained equal 
amount of buffer instead of sample. The sample and its respective control were run together. After 10 minutes of exposure, $1 \mathrm{ml}$ of Greiss reagent (prepared freshly by mixing equal volumes of $1 \%$ sulphanilamide in $5 \%$ phosphoric acid and $0.1 \% \mathrm{~N}$-1-napthyl ethylene diamine) was added to each tube and the absorbance was measured at $543 \mathrm{~nm}$.

The APX (EC 1.11.1.11) activity was measured according to the methods of (Nakano and Asada 1981). The reaction mixture contained $50 \mathrm{mM}$ potassium phosphate buffer $(\mathrm{pH}$ 7.0), $0.5 \mathrm{mM}$ ascorbic acid, $0.1 \mathrm{mM}$ hydrogen peroxide, and $0.1 \mathrm{~mL}$ of enzyme extract in a total volume of $1 \mathrm{ml}$. The concentration of oxidized ascorbate was calculated by the decrease in absorbance at $290 \mathrm{~nm}$. The absorption coefficient was $2.8 \mathrm{mM}^{-1} \mathrm{~cm}^{-1}$. One unit of APX was defined as $1 \mathrm{mmol}$ $\mathrm{ml}^{-1}$ ascorbate oxidized $\min ^{-1}$ (Hossain et al., 2006).

\section{Extraction of protein and gel electrophoresis}

Protein were extracted by homogenizing the $0.333 \mathrm{gm}$ freezedried shoot sample in pre-chilled mortar and pestle using 1 $\mathrm{ml}$ of extraction buffer consisting of $0.2 \mathrm{M}$, tris hydroxymethyl aminomethane (Tris); $0.001 \mathrm{M}$ ethylene diamine tetra acetic acid (Na2+EDTA); 12\%, glycerol; $0.01 \mathrm{M}$, dithiothreitol (DTT); and $0.05 \mathrm{mM}$ phenyl methyl sulfonyl fluoride (PMSF). The samples were centrifuged at $15000 \times \mathrm{g}$ for $15 \mathrm{~min}$, and the supernatant was used for determination of total protein content. The protein sample was added with an equal volume of cracking puffer $(0.125 \mathrm{M}$, Tris.Cl; $\mathrm{pH}$ 6.8; 4\%, SDS; 20\%, glycerol; $10 \%, \beta-$ mercaptoethanol and $0.01 \%$, bromophenol blue) and was denatured by boiling in water bath at $90^{\circ} \mathrm{C}$ for $3 \mathrm{~min}$. Protein samples $(\sim 500 \mu \mathrm{g})$ were electrophoresed in a discontinuous SDS polyacrylamide gel following Laemmli (1970), using a $12 \%$ resolving gel $(0.375 \mathrm{M}$, Tris. $\mathrm{Cl} ; \mathrm{pH} 8.8)$ and $4 \%$ stacking gel $(0.125 \mathrm{M}$, Tris-Cl; $\mathrm{pH} 6.8)$ in Tris-glycine buffer (0.025M, Tris; $\mathrm{pH} 8.3$; 0.192M, glycine; $0.1 \%$, SDS) for 16 $\mathrm{hr}$, constantly at $20 \mathrm{~mA}$. Staining of the gel was done using $0.2 \%(\mathrm{w} / \mathrm{v})$ Commassie Brilliant Blue R-250 in $12.5 \%(\mathrm{w} / \mathrm{v})$ trichloroacetic acid (TCA). The position of the protein band in the gel was expressed to compare with standard protein markers with known molecular weight.

\section{Statistical analysis}

All the data were statistically analyzed by two-way analysis of variance (ANOVA). The least significant difference (LSD) method was used to test the difference between treatments and $\mathrm{p} \leq 0.05$ was considered statistically significant. Statistical analyses were performed with SPSS packet software.

\section{Conclusions}

This study proved the beneficial effects of salicylic acid (SA) and ascorbic acid (ASA) on growth characters, some biochemical constituents under salinity stress conditions of date palm cv. Nersy plants at in vitro conditions. These effects may be attributed to the protective role of SA and ASA in plant cells from the oxidative stress induced by salinity and by increasing the antioxidant activity of enzymes such as SOD and APX, appearing new protein bands. We also concluded that application of SA and ASA combined together to media are the most effective treatment to enhance growth date palm plants under salinity stress conditions. The combined effect of SA and ASA leads to synthesis of additional proteins bands, providing a reason for bearing more salt stress.

\section{Acknowledgements}

Author thanks all the researchers in the Date Palm Research Center(Department of plant propagation), and Laboratory of Genetic Engineering in the College of Agriculture

\section{References}

Agarwal S, Sairam RK, Srivastava GC, Meena RC (2005) Changes in antioxidant enzymes activity and oxidative stress by abscisic acid and salicylic acid in wheat genotypes. Biol Plant 49:541-550.

Alkhateeb SA, Alkhateeb AA, Solliman Mel-D. (2015). In vitro response of date palm (Phoenix dactylifera $\mathrm{L}$.) to $\mathrm{K} / \mathrm{Na}$ ratio under saline conditions. Biol Res.11:48:63.

Al-Mayahi AM (2015) The compound effects of $\mathrm{NaCl}$ and gibberellic acid on the growth and development of in vitro date palm (Phoenix dactylifera $\mathrm{L}$.) plantlets cv. Showathy. J K Saud Univ Agric Sci. 26(2):1-33

Amin AA, El-Sh M, Rashad FAEG (2008) Changes in morphological, physiological and reproductive characters of wheat plants as affected by foliar application with salicylic acid and ascorbic acid. Aust J Basic and appl Sci. 2(2): 252261.

Apte SK, Bhagwat AA (1998) Salinity-stress-induced proteins in two nitrogen- fixating Anabaena strains differentially tolerant to salt. J Bacteriol. 171: 909-15.

Athar HR, Khan A, Ashraf M (2008) Exogenously applied ascorbic acid alleviates salt-induced oxidative stress in wheat. Environ Exp Bot. 63(1- 3):224-231.

Azooz MM, Shaddad MA, Abdel-Latef AA (2004) Leaf growth and $\mathrm{K}+/ \mathrm{Na}+$ ratio as an indication of the salt tolerance of three sorghum cultivars grown under salinity stress and IAA treatment. Acta Agron Hung. 52: 287-296.

Azooz MM, Al-Fredan MA (2009) The inductive role of vitamin $\mathrm{C}$ and its mode of application on growth, water status, antioxidant enzyme activities and protein patterns of Vicia faba L. cv. Hassawi grown under seawater irrigation Amer J Plant Physiol 4: 38-51

Beltagi MS (2008) Exogenous ascorbic acid (vitamin C) induced anabolic changes for salt tolerance in chick pea. Afr J Plant Sci. 2: 118-123.

Bartels D and Sunkar R (2005).Drought and salt tolerance in plants .Critical Rev. Plant Sci.24:23-58.

Borsani O, Valpuesta V, Botella MA (2001) Evidence for a Role of Salicylic Acid in the Oxidative Damage Generated by $\mathrm{NaCl}$ and Osmotic Stress in Arabidopsis Seedlings. J Plant Physiol. 126: 1024-1030. Choudhury, S, Panda, S. K. (2004). Role of salicylic acid in regulating cadmium induced oxidative stress in Oryza sativa L. roots. Bulg J Plant Physiol. 30 (3-4): 95-110.

Colom MR, Vazzana C (2001) Drought stress effect on three cultivars of Eragrostis curvula: photosynthesis and water relation. J Plant Grow Reg. (34):195-202.

Das K, Samanta L, Chainy GBN (2000) A modified spectrophotometric assay of superoxide dismutase using nitrite formation by superoxide radicals. Ind J Biochem Biophys. 37(3): 201-204.

Dolatabadian A, Jouneghani RS (2009) Impact of exogenous ascorbic acid on antioxidant activity and some physiological traits of common bean subjected to salinity stress. Notulae Botanicae Horti Agrobotanici Cluj-Napoca. 37, 165-172.

El-Bassiouny HM, Mostafa HA, El-Khawas SA, Hassanein RA, Khalil SI, Abd El-Monem AA (2008) Physiological responses of wheat plant to foliar treatments with arginine or putrescine. Aust J Basic Appl Sci. 2(4): 1390-1403.

El-Tayeb MA ( 2005) Response of barley grains to the interactive effect of salinity and salicylic acid, Plant Growth Regul. 45: 215-224.

Erda S, Aydın M, Genisel M, Taspınar MS, Dumlupinar R, Kaya O, Gorcek Z (2011) Effects of salicylic acid on wheat salt sensitivity. Afr J Biotechnol. 10: 5713-5718. 
Farahat MM, Azza AM, Mona HM, Sahar MZ (2013) Salt tolerance in Grevillea robusta seedlings via foliar application of ascorbic acid. Middle-East J Scien Res. 14 (1), 09-15.

Flowers T (2004) Improving crop salt tolerance. J Exp Bot. 55:307-19.

Foyer CH (1993) Ascorbic acid. In. R.G.Alscher and J.L.Hess (eds.) Antioxidants in higher plants. pp 31-58. CRC Press, Inc. Florida.

Foyer CH, Noctor G (2003) Redox sensing and signalling associated with reactive oxygen in chloroplasts, peroxisomes and mitochondria. Physiol Plant. 119: 355-364.

Gomathi R, Vasantha S, Shiyamala S, Rakkiyappan P (2013) Differential accumulation of salt induced proteins in contrasting sugarcane genotypes. EJBS 6 (1):7-11.

Gopala Rao P, Reddy CD, Ramaiah JK (1987) Effect of Bvitamins on the protein component of clusterbeans Cyamopsis tetragonoloba. Ann Bot 59: 281-284. Physio Bioch. 6:46-90.

Hamdia MA, Shaddad MAK (2010) Salt tolerance of crop plants. J Stress Phys Biochem. 6: 64-90.

Hossain Z, Mandal AKA, Datta SK (2006) Development of $\mathrm{NaCl}$ tolerant strain in Chrysanthemum morifolium Ramat. Through in vitro mutagenesis. Plant Biol. 8: 450-461.

Jahnke LS, White AL (2003) Long-term hyposaline and hypersaline stresses produce distinct antioxidant responses in the marine algae Dunaliella tertiolecta. J Plant Physiol. 160: 1193-1202.

Janda T, Horvath G, Szalai G, Paldi E (2007) Role of salicylic acid in the induction of abiotic stress tolerance. In Hayat $S$, Ahmad A, eds .Salicylic Acid, A plant Hormone. Springer Publishers, Dordrecht, The Netherlands.

Jiang Y, Huang B (2002) Drought and heat stress injury to two cool-season turf grasses in relation to antioxidant metabolism and lipid peroxidation. Sci. 4:436-442

Kaya C, Kirnak H, Higgs D, and Saltati K (2002) Supplementary calcium enhances plant growth and fruit yield in strawberry cultivars grown at high $(\mathrm{NaCl})$ salinity. Sci Hor. 26:807-820.

Khan W, Prithiviraj, B, Smith DL (2003) Photosynthetic responses of corn and soybean to foliar application of salicylates. J Plant Physiol. 160:485-492.

Kong-Ngern K, Daduang S, Wongkham CH, Bunnag S, Kosittrakuna M, Theerakulpisata P (2005) Protein profiles in response to salt stress in sheaths of rice seedlings. Sci Asia. 31: 403-408.

Laemmli UK (1970) Cleavage of structural proteins during the assembly of the head bacteriophage T4. Nature. 227, 680-685.

Lee DH, Kim YS, Lee CB (2001) The inductive responses of the antioxidant enzymes by salt stress in the rice (Oryza sativa L.). J Plant Phyiol. 158: 737-745.

Mittler R (2002) Oxidative stress, antioxidants and stress tolerance. Trends Plant Sci. 7:405-410.

Munns R (2005) Genes and salt tolerance: bringing them together. New Phytol. 167:645-663.

Murashige T, Skoog F (1962) A revised medium for rapid growth and bioassays with tobacco tissue culture. Physiol Plant. 15: 473-497.
Nikolova MT and Ivancheva SV (2005) Quantitative flavonoid variations of Artemisia vulgaris L. and Veronica chamaedrys L. In relation to altitude and polluted environment. Acta Biol Szegediensis. 49:29-32.

Noctor G, Foyer C (1998) Ascorbate and glutathione: Keeping active oxygen under control. Ann Rev Plant Physiol. Plant Mol Biol. 49:249-279.

Pignocchi C, Foyer CH (2003) Apoplastic ascorbate metabolism and its role in the regulation of cell signalling. Curr Opin Plant Biol. 6:379-389.

Porra RJ (2002) The chequered history of the development and use of stimulation quantions for the accurate determination of chlorophylls A and B. Photosynthesis Res. 73: 149-156.

Schutz M, Fangmeir E (2001) Growth and yield response of spring wheat (Triticum aestivum L. cv. Minaret) to elevated CO2 and water limitation. Environ Pollu. 11:187-194.

Senaratna T, Touchell D, Bumm E, Dixon K (2000) Acetyl salicylic acid (asprin) and salicylic acid induce multiple stress tolerance in bean and tomato plants. Plant Grow Regul. 30: $157-161$.

Shao HB, Chu LY, Jaleel CA (2008) Water-deficit stressinduced anatomical changes in higher plants. CR Biologies. 331(3):215-25.

Slaymaker DH, Navarre DA, Clark D, Del-Pozo O, Martin GB, Klessig DF (2002) The tobacco salicylic acid-binding protein 3 (SABP3) is the chloroplast carbonic anhydrase, which exhibits antioxidant activity and plays a role in the hypersensitive defense response. Proc Natl Acad Sci USA. 99:11640-11645.

Smirnoff N, Wheeler GL (2000) Ascorbic acid in Plants: biosynthesis and function. Critical reviews in plant sciences. 19: 267-290.

Smirnoff, Ned (2005) Antioxidants and Reactive Oxygen Species in Plants. Blackwell Pub. Ltd ISBN 10-1-4051-2529-2.

Stevens J, Senaratna T, Sivasithamparam K (2006) Salicylic acid induces salinity tolerance in tomato (Lycopersicon esculentum cv. Roma): Associated changes in gas exchange, water relations and membrane stabilisation. Plant Grow Regu. 49, 77-83.

Sudhakar C, Lakshmi A, Giridarakumar S (2001) Changes in the antioxidant enzyme efficacy in two high yielding genotypes of mulberry (Morus alba L.) under $\mathrm{NaCl}$ salinity. Plant Sci.161:613-619.

Yaish MW (2015) Proline accumulation is a general response to abiotic stress in the date palm tree (Phoenix dactylifera $\mathrm{L}$.). Genet Mol Res. 14(3): 9943-9950.

Yaish MW, Sunkar R, Zheng Y, Ji B, Farooq SA, Al-Yahyai R (2016) A genome-wide identification of the miRNAome in response to salinity stress in date palm (Phoenix dactylifera L.). Front Plant Sci. 6:946.

Zaid A (Ed.). 2002. Date Palm Cultivation, Rev Ed. FAO, Rome 